\title{
Viability of recalcitrant Araucaria angustifolia seeds in storage and in a soil seed bank
}

\author{
Ezequiel Gasparin ${ }^{1}$ José M. R. Faria ${ }^{2}$ Anderson C. José ${ }^{2}$ - Olivia A. O. Tonetti ${ }^{2}$. \\ Rodrigo A. de Melo $^{2} \cdot$ Henk W. M. Hilhorst ${ }^{3}$
}

Received: 17 March 2019/ Accepted: 8 May 2019/Published online: 28 June 2019

(C) The Author(s) 2019

\begin{abstract}
Araucaria angustifolia (Bertol.) Kuntze is a representative species of the Mixed Ombrophilous Forest in the Atlantic Forest Biome of Brazil. The development of a germplasm conservation protocol for long-term seed bank storage is compromised for this species, as it is sensitive to desiccation. Furthermore, in situ establishment of a soil seed bank in its natural habitat may be limited. This study evaluates the storability of two provenances of $A$. angustifolia seeds and their behavior in an artificial soil seed bank in two forest environments (understory and edge). Results show that both seed provenances may be stored at $5{ }^{\circ} \mathrm{C}$ for approximately 12 months, retaining high viability. The subsequent decrease in germination was associated with a reduction and an increase in seed water content, as well as with increased electrical conductivity. In the understory environment, seed viability was above $85 \%$ for the first 60 days, and at the end of the experiment (270 days), seedlings emerged. However, at the forest
\end{abstract}

Project funding: E. G. received a fellowship from CAPES (Coordination for the Improvement of Higher Level Personnel).

The online version is available at http://www.springerlink.com.

Corresponding editor: Tao $\mathrm{Xu}$.

Ezequiel Gasparin

ezequiel.gasparin@ufsm.br

1 Departamento de Ciências Florestais, Universidade Federal de Santa Maria (UFSM), Avenida Roraima, 1000, Camobi, Santa Maria, RS 97105-900, Brazil

2 Departamento de Ciências Florestais, Universidade Federal de Lavras (UFLA), Caixa Postal 3017, Lavras, MG, Brazil

3 Wageningen Seed Lab, Laboratory of Plant Physiology, Wageningen University, Droevendaalsesteeg 1, 6708 PB Wageningen, The Netherlands edge, there was a total loss of seed viability after 120 days associated with a reduction in water content and high predation. It is concluded, therefore, that short-term storage of $A$. angustifolia seeds is possible in a cold room, which is fundamental to supply seed demand outside the production period. Forest cover conservation is important for regeneration and conservation of the species.

Keywords Brazilian pine - Desiccation sensitivity · Forest cover $\cdot$ Soil seed bank $\cdot$ Storability

\section{Introduction}

Many species produce desiccation- tolerant (orthodox) seeds which may survive for long periods, hundreds of years in some cases, with low water content and resume development when rehydrated (Bewley et al. 2013). On the other hand, some seeds are dispersed with high water contents and do not tolerate desiccation (recalcitrant). They may be stored for a short period of time as long as they are hydrated. Considering habitat features, species that produce recalcitrant seeds are common in moist and nonseasonal environments and are less common or absent in dry and highly seasonal regions (Tweddle et al. 2003). Differences between orthodox and recalcitrant seed behavior may be due to the process of natural selection, given the different environmental conditions required for their establishment (Barbedo and Bilia 1998).

Ex situ longevity of orthodox seeds, when related to the environmental features of the collection site, demonstrates that seeds from hot and dry environments are viable longer than those collected in moist and cold places (Probert et al. 2009). Recalcitrant seeds have low storability and lifespan, and pose significant challenges to ex situ conservation in 
germplasm banks (Umarani et al. 2015). In addition to their intolerance to desiccation below water contents that limit water freezing, recalcitrant seeds have a high risk of ice crystal formation which may be lethal when conventional orthodox seed storage methods are employed (Walters 2015).

There is a continuum in desiccation sensitivity among seeds, ranging from those that are highly sensitive to desiccation and cooling, to those that tolerate desiccation to a low water content and low storage temperatures. If only recalcitrant seeds are considered, behavior among species is also variable since not all seeds lose viability at the same water content (Berjak and Pammenter 2000; Bewley et al. 2013). Within the same genus (Araucaria), different behavior is observed among species. For example, seeds of A. cunninghamii Sweet may be desiccated to $7 \%$ water content and are classified as orthodox, whereas A. hunsteinii $\mathrm{K}$. Schum seed tolerate desiccation to only $32 \%$ and are classified as recalcitrant (Tompsett 1982).

Seed longevity for most tropical species is unknown, both under artificial storage conditions and in their natural habitat (Vazquez-Yanes and Orozco-Segovia 1993). After dispersal, seeds may germinate immediately or persist for a given period in the soil, forming a seed bank (Thompson 2000; Fenner and Thompson 2005), which comprises all viable seeds in a given soil layer (Saatkamp et al. 2014). Soil seed bank persistence may be calculated directly or indirectly by means of simulation-burying the seeds in the soil and verifying their viability through time (direct method) or by removing samples from the soil to be exposed to favorable germination conditions and later identification (indirect method) (Saatkamp et al. 2009).

The study of seed behavior in the soil is fundamental to understanding population dynamics. Seed persistence is influenced by physical and physiological features as well as by biotic and abiotic factors in the environment (Long et al. 2015). The state of habitat conservation appears to be relevant for seed persistence in the soil. Cryptocarya aschersoniana Mez, a species from the Brazilian Atlantic Forest, produces recalcitrant seeds that form a transient seed bank; however, disturbed environments are unfavorable to the germination and regeneration of the species (Tonetti et al. 2015).

Given the high level of fragmentation of the Atlantic Forest biome, many species face extinction and have poor natural regeneration, thereby compromising their permanence in the ecosystem. Araucaria angustifolia (Brazilian pine) is a dioecious species classified as a long-lived pioneer that dominates the Mixed Ombrophilous Forest within the Atlantic Forest biome (Souza et al. 2008). Regeneration of Brazilian pine is associated with open-canopy microsites since the species is light-demanding and regeneration fails under a closed-canopy (Souza et al. 2008). It occurs naturally from Rio Grande do Sul (RS) in the south to Minas
Gerais (MG) in the southeastern regions of Brazil (Carvalho 2002). Phylogeography studies show that in the past, pre-Columbian humans played an important role in the dispersion of A. angustifolia, demonstrating signs of recent and rapid expansion (Lauterjung et al. 2018). However, due to logging, especially between the $1930 \mathrm{~s}$ and $1950 \mathrm{~s}$, the species now occupies about 1 or $2 \%$ of its original area (Guerra et al. 2000) and is currently regarded as highly endangered (IUCN 2016). Besides its importance for the production of wood, its seeds are widely consumed by humans and the local fauna because of its nutritional value (Thys et al. 2010). These factors also contribute to poor or absent regeneration in some populations due to heavy seed collection and predation. The seeds are sensitive to desiccation (Tompsett 1984) and knowledge of their physiological behavior as well as their potential to remain viable in the soil is fundamental for the conservation of the species and the recovery of degraded forest sites.

This study evaluates the storability of A. angustifolia seeds from two collection areas, and their behavior in a soil seed bank in different forest environments. It is hypothesized that seeds remain viable under cold storage for a short period, and that provenance influences their storability. In addition, if the forest cover is maintained, a transient seed bank of A. angustifolia can be established.

\section{Materials and methods}

\section{Seed collection and processing}

Seeds were collected in two areas of natural occurrence of the species. The first lot (RS provenance) originated from São Francisco de Paula National Forest (FLONA-SFP), classified as a Mixed Ombrophilous Forest (Leite 2002) $\left(29^{\circ} 25^{\prime} 22,4^{\prime \prime} \mathrm{S} ; 50^{\circ} 23^{\prime} 11,2^{\prime \prime} \mathrm{W}\right)$, Rio Grande do Sul, and the second (MG provenance) from forest remnants at Aiuruoca (Minas Gerais), classified as Lower Montane Ombrophilous Forest (Oliveira-Filho and Fontes 2000), $\left(21^{\circ} 13^{\prime} 55,0^{\prime \prime} \mathrm{S}\right.$; $\left.44^{\circ} 58^{\prime} 42,0^{\prime \prime} \mathrm{W}\right)$. Seeds were collected from 12 trees in each region between April and May in 2013 and in 2014.

After collection, seeds were placed in a water-filled container and seeds that floated were discarded; those that sank were used in the experiment (Wendling and Delgado 2008). Seeds displaying visible signs of attack by $C y$ dia araucariae (Pastrana) larvae were also discarded. Afterwards, seeds were dried at $25 \pm 2{ }^{\circ} \mathrm{C}$ for $24 \mathrm{~h}$ to eliminate superficial moisture from processing.

\section{Seed storage}

Seeds collected in 2013 were placed in semi-permeable sealed polyethylene plastic bags and stored in a cold room 
$\left(5 \pm 1{ }^{\circ} \mathrm{C} / \mathrm{RH} 35-40 \%\right)$. Samples were removed periodically to determine water content of seeds and embryos, viability by germination and tetrazolium tests, respiration rates and predation percentage. The following storage times were evaluated: zero (immediately after collection), 3, 12, 19 and 26 months for MG provenance and zero, 4, 12, and 18 months for RS provenance.

\section{Water content, tetrazolium test and electrical conductivity}

Water content was determined by oven drying at $103 \pm 2{ }^{\circ} \mathrm{C}$ for $17 \mathrm{~h}$ (ISTA 1996) and calculated on a fresh weight basis using four replicates of five cross-sectioned seeds/intact embryos.

A tetrazolium test used four replicates of 15 embryos. Seeds were incubated in a 2,3,5 triphenyl tetrazolium chloride solution at $0.2 \%$ concentration for $4 \mathrm{~h}$ at $40{ }^{\circ} \mathrm{C}$ in the dark. The embryos were then washed with distilled water and kept submerged in water until the evaluation by color, following recommendations of Abreu et al. (2012). The results were presented as viability percentage.

The electrical conductivity test was carried out with four replicates of five individual seeds without tegument, previously weighted with an electronic precision scale and soaked in $50 \mathrm{~mL}$ of deionized water. Seeds were kept at $25 \pm 2{ }^{\circ} \mathrm{C}$ in the dark for $24 \mathrm{~h}$. The leachate was later measured and expressed as $\mu \mathrm{S} \mathrm{cm}^{-1} \mathrm{~g}^{-1}$ seed using a Digimed electrical conductivity meter (DM 31$)^{\circledR}$.

\section{Germination tests}

These were carried out by cutting part of the seed coat approximately $3 \mathrm{~mm}$ from the proximal end to accelerate germination and make it uniform (Moreira-Souza and Cardoso 2003). Seeds were surface-sterilized with sodium hypochlorite (2\%) for $10 \mathrm{~min}$, rinsed in running water, and sown over moistened autoclaved sand in plastic trays $(51 \times 26 \times 7 \mathrm{~cm})$. Seeds were kept in a Mangelsdorf germinator $\left(25 \pm 2{ }^{\circ} \mathrm{C}\right)$ under constant light. Four replicates of 20 seeds per treatment were used. Germination was scored weekly for 70 days, evaluating radicle protrusion and normal seedlings formation, (i.e., those with primary or a set of secondary roots, well-developed hypocotyl, epicotyl and presence of needles).

\section{Respiration rate and $\mathrm{X}$-rays}

Respiration was evaluated in four replicates of 15 seeds placed in a container with $600 \mathrm{~mL}$ and incubated for $24 \mathrm{~h}$ at $25{ }^{\circ} \mathrm{C}$. The containers were closed with a rubber stopper to prevent gas exchange with the environment while allowing the entrance of the needle for air collection and subsequent measurement of $\mathrm{CO}_{2}$ and $\mathrm{O}_{2}\left(\% \mathrm{~g}^{-1}\right.$ day $\left.^{-1}\right)$ by a PBI-Dansensor CHECKPOINT $\mathrm{O}_{2} / \mathrm{CO}_{2}$.

$\mathrm{X}$-ray images were acquired of four replicates of 20 seeds, using automatic radiographic analysis by a digital Faxitron HP MX-20. Predation percentage by larvae was evaluated by visualizing the radiographic images. Subsequently, the radiographed seeds were set to germinate to assess their viability.

\section{Soil seed bank}

The experiment was installed in a fragment of Seasonal Semi-deciduous Montane Forest $\left(21^{\circ} 20^{\prime} 35,41^{\prime \prime} \mathrm{S}\right.$; $44^{\circ} 58^{\prime} 58,58^{\prime \prime} \mathrm{W}$ ) at Lavras (MG) in May 2014 (seed dispersal period) using freshly collected seeds (MG provenance). Immediately after collection, germination was determined (radicle protrusion and normal seedlings formation), water content (seed and embryo), and predation percentage. The artificial soil seed bank was set in two distinct environments: understory and forest edge, set up in a completely randomized design with four replicates of 160 seeds each. Seeds were placed in nylon mesh bags $(5 \times 30 \mathrm{~cm})$ covered by litter and protected by metal grids $(120 \mathrm{~cm}$ length $\times 80 \mathrm{~cm}$ width $\times 15 \mathrm{~cm}$ height; mesh $1 \times 1 \mathrm{~cm})$ to avoid predation by rodents. Seeds were sampled at intervals from the seed bank and evaluated for germination, water content and predation percentage, four times in the understory (30,60, 190 and 270 days) and three times at the forest edge (30,60 and 120 days).

The experiment ended in January 2015. At each assessment of the seed bank, soil samples were collected to determine water content (four replicates of $70 \mathrm{~g}$ of soil each/oven drying at $105^{\circ} \mathrm{C}$ for $24 \mathrm{~h}$ ). Climate data for the period were obtained from the Climatological Station (Department of Engineering, Federal University of Lavras), located $10 \mathrm{~km}$ from the study area.

\section{Statistical analysis}

All experiments were set in a completely randomized design. Data were submitted to normality by the ShapiroWilk test and homoscedasticity by the Bartlett test. Germination data was arc-sine transformed to attend the normality/homoscedasticity, and then subjected to ANOVA analysis. Means were compared by Tukey test at 5\% probability. Data analysis were carried out using Sisvar software (Ferreira 2008). 


\section{Results}

\section{Seed storage}

Seed viability after collection, verified by germination tests, was similar for both seed lots. However, viability assessed by tetrazolium showed higher averages than those in germination tests for the MG provenance and lower for the RS provenance (Table 1; Fig. 1).

During a 12-month storage, no significant differences were observed between percent radicle protrusion and normal seedling values for the MG provenance (Fig. 1) or for seed water content. After 12 months storage, germination was reduced significantly and lowest at 26 months, statistically different from values at 19 months. Viability reduction at the end of the storage period coincided with a significant decrease in seed and embryo water contents. There was a decrease of 11.6 (seed) and 4.4 (embryo) percentage points when compared to initial values.

There was a decrease in embryo viability throughout the storage period when assessing MG provenance using the tetrazolium test, resulting in a complete loss of viability by 26 months. There were no significant changes in electrical conductivity of the seeds until 19 months. However, in the final determination, electrical conductivity increased from $89.3 \mu \mathrm{S} \mathrm{cm}^{-1} \mathrm{~g}^{-1}$ (initial point) to $433.4 \mu \mathrm{S} \mathrm{cm}^{-1} \mathrm{~g}^{1}$ (final). Respiration rate $\left(\mathrm{O}_{2}\right.$ and $\left.\mathrm{CO}_{2}\right)$ and percent seed predation did not differ throughout evaluations except for the RS provenance when $\mathrm{CO}_{2}$ decreased during storage (Table 1).

RS provenance seeds showed similar behavior as those of the MG provenance, maintaining viability for a 12-month storage period. However, after 18 months

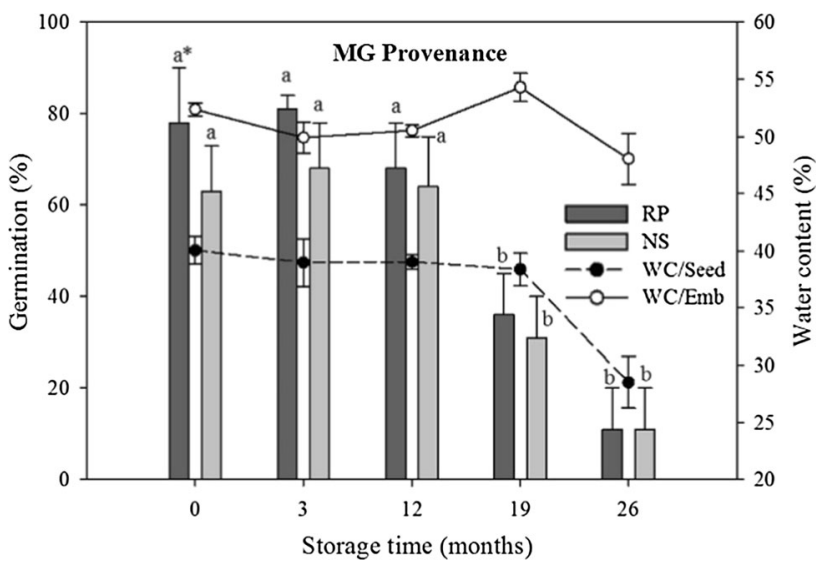

Fig. 1 Germination and water content of Araucaria angustifolia seeds (MG provenance) during cold storage. RP: radicle protrusion; NS: normal seedling; WC/Seed: seed water content; WC/Emb: embryo water content. *Means followed by the same letter were not different according Tukey test at 5\%. Bars represent standard deviation

viability decreased significantly. Normal seedling values were not significantly different throughout the storage period (Fig. 2). After 25 months of storage, there was a total loss of viability with increasing fungi infection during storage.

In the final assessment of the RS provenance seed, water contents increased significantly compared to the initial level. For embryos however, there was no significant difference in water contents during storage. Embryo viability, as verified by the tetrazolium test, was maintained during storage (Table 1). Electrical conductivity increased significantly from 14.8 (time zero/after collection) to $84.6 \mu \mathrm{S} \mathrm{cm}^{-1} \mathrm{~g}^{-1}$ (18 months). In addition, the $\mathrm{O}_{2}$ consumption rate was higher for fresh seeds than for those

Table 1 Average values of water content, viability (tetrazolium test), electrical conductivity, respiration and seed predation of different provenances seeds stored at $5 \pm 1{ }^{\circ} \mathrm{C} / \mathrm{RH}(35-40 \%)$

\begin{tabular}{|c|c|c|c|c|c|c|c|c|}
\hline & \multirow[t]{2}{*}{$\begin{array}{l}\text { Time } \\
\text { (months) }\end{array}$} & \multicolumn{2}{|c|}{$\begin{array}{l}\text { Water content } \\
(\%)\end{array}$} & \multirow[t]{2}{*}{$\begin{array}{l}\text { Viability } \\
(\%)\end{array}$} & \multirow[t]{2}{*}{$\begin{array}{l}\text { Electrical conductivity } \\
\left(\mu \mathrm{S} \mathrm{cm}^{-1} \mathrm{~g}^{-1}\right)\end{array}$} & \multicolumn{2}{|l|}{ Respiration rate } & \multirow[t]{2}{*}{$\begin{array}{l}\text { Predation } \\
\text { percentage }(\%)\end{array}$} \\
\hline & & Seed & Embryo & & & $\begin{array}{l}\mathrm{O}_{2} \\
\left(\% \mathrm{~g}^{-1} \mathrm{day}^{-1}\right)\end{array}$ & $\begin{array}{l}\mathrm{CO}_{2} \\
\left(\% \mathrm{~g}^{-1} \mathrm{day}^{-1}\right)\end{array}$ & \\
\hline \multirow{5}{*}{$\begin{array}{l}\text { MG } \\
\text { provenance }\end{array}$} & 0 & $40.1^{\text {aa }}$ & $52.4^{\mathrm{ab}}$ & $97^{\mathrm{a}}$ & $89.28^{\mathrm{b}}$ & $0.165^{\mathrm{a}}$ & $0.577^{\mathrm{a}}$ & $9^{\mathrm{a}}$ \\
\hline & 3 & $39.0^{\mathrm{a}}$ & $49.9^{\mathrm{bc}}$ & $88^{\mathrm{a}}$ & $72.95^{\mathrm{b}}$ & $0.129^{\mathrm{a}}$ & $0.918^{\mathrm{a}}$ & $8^{\mathrm{a}}$ \\
\hline & 12 & $39.0^{\mathrm{a}}$ & $50.5^{\mathrm{bc}}$ & $58^{\mathrm{b}}$ & $46.79^{\mathrm{b}}$ & $0.152^{\mathrm{a}}$ & $0.690^{\mathrm{a}}$ & $8^{\mathrm{a}}$ \\
\hline & 19 & $38.4^{\mathrm{a}}$ & $54.3^{\mathrm{a}}$ & $17^{\mathrm{c}}$ & $96.16^{\mathrm{b}}$ & $0.161^{\mathrm{a}}$ & $0.708^{\mathrm{a}}$ & $3^{\mathrm{a}}$ \\
\hline & 26 & $28.5^{\mathrm{b}}$ & $48.0^{\mathrm{c}}$ & $0^{\mathrm{c}}$ & $433.38^{\mathrm{a}}$ & - & - & $6^{\mathrm{a}}$ \\
\hline \multirow{4}{*}{$\begin{array}{l}\mathrm{RS} \\
\quad \text { provenance }\end{array}$} & 0 & $39.0^{\mathrm{b}}$ & $51.7^{\mathrm{a}}$ & $62^{\mathrm{a}}$ & $14.85^{\mathrm{b}}$ & $0.172^{\mathrm{a}}$ & $0.595^{\mathrm{a}}$ & $8^{\mathrm{a}}$ \\
\hline & 4 & $39.0^{\mathrm{b}}$ & $49.1^{\mathrm{a}}$ & $63^{\mathrm{a}}$ & $14.45^{\mathrm{b}}$ & $0.087^{\mathrm{bc}}$ & $0.159^{\mathrm{b}}$ & $6^{\mathrm{a}}$ \\
\hline & 12 & $41.8^{\mathrm{b}}$ & $52.4^{\mathrm{a}}$ & $43^{\mathrm{a}}$ & $19.15^{\mathrm{b}}$ & $0.077^{\mathrm{c}}$ & $0.144^{\mathrm{b}}$ & $4^{\mathrm{a}}$ \\
\hline & 18 & $46.4^{\mathrm{a}}$ & $51.9^{\mathrm{a}}$ & $25^{\mathrm{a}}$ & $84.65^{\mathrm{a}}$ & $0.130^{\mathrm{ab}}$ & $0.109^{b}$ & $15^{\mathrm{a}}$ \\
\hline
\end{tabular}

${ }^{a}$ Means followed by the same letter indicate no difference according to Tukey test at $5 \%$ 


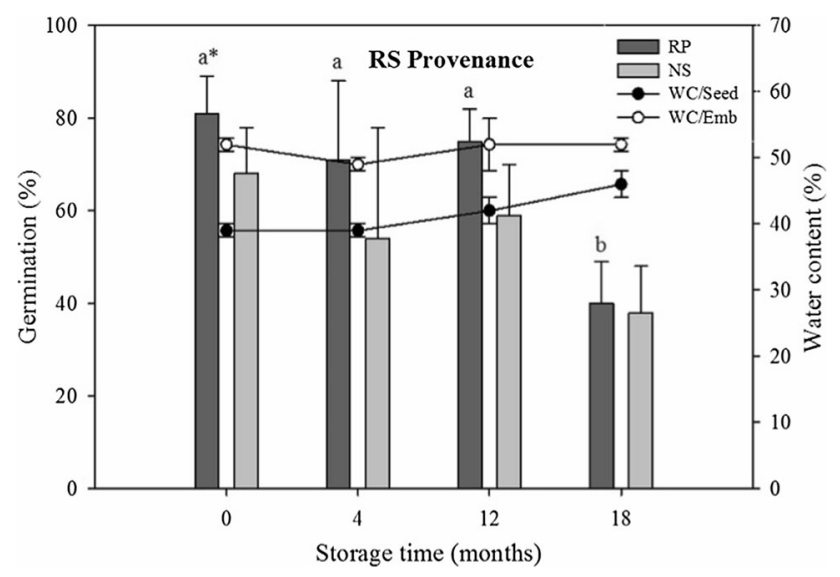

Fig. 2 Germination and water content of Araucaria angustifolia seeds (RS provenance) during cold storage. RP: radicle protrusion; NS: normal seedling; WC/Seed: seed water content; WC/Emb: embryo water content. *Means followed by the same letter showed no difference according to Tukey test at 5\%. Bars represent standard deviation

stored for 18 months $\left(0.17\right.$ and $0.13 \% \mathrm{~g}^{-1}$ day $^{-1}$ of $\mathrm{O}_{2}$, respectively), whereas $\mathrm{CO}_{2}$ release was high only for fresh seeds. Percent predation showed no significant difference throughout the storage period (Table 1).

$\mathrm{X}$-ray analysis of A. angustifolia seeds showed infestation by the larvae of the Tortricid moth, Cydia araucariae Pastrana in both lots; the values were relatively low at approximately $10 \%$. In some cases, the presence of larvae was observed only in the tegument; in others, damage also occurred in the megagametophyte and embryo (Fig. 3a-b). In addition, at the end of the storage period, germinated seeds were observed as well as larvae predation, which damaged the embryo and reserve tissues, resulting in loss of viability (Fig. 3c). X-ray analysis also showed a reduction of the space occupied by the megagametophyte for MG provenance throughout the storage period, possibly due to water loss that led to its shrinkage (Fig. 3d). Loss of water was also a possible cause of the hardening of the megagametophyte observed at the end of the storage period.

\section{Soil seed bank}

Araucaria angustifolia seeds collected in 2014 (MG provenance) and used in the artificial soil seed bank had an initial water content of $37.5 \% \pm 0.8 \%$ for seeds and $52.0 \% \pm 1.3 \%$ for embryos. Initial viability, evaluated by the laboratory germination test, showed radicle protrusion of $91 \% \pm 5 \%$ and normal seedlings of $85 \% \pm 11 \%$. Initial percentage predation due to infestation by Cydia araucariae was low $(3 \% \pm 3 \%)$ (Figs. 4 , 5/time zero-after collection).

Radicle protrusion, normal seedling and soil water content values varied significantly $(p \leq 0.05)$ throughout the 270-day evaluation period of seeds in the seed bank in the understory (Fig. 4a, b). Seed viability was above $85 \%$ up to 60 days after the bank was created. After this period,
Fig. 3 Araucaria angustifolia seeds $\mathrm{x}$-rays during cold room storage. A RS Provenance and B MG Provenance seeds after collection; larvae are present (arrows). C RS Provenance seeds stored for 18 months; germination (asterisk) and predation (arrows). D Reduction of the volume occupied by seed megagametophyte (arrow) stored for 26 months (MG provenance)
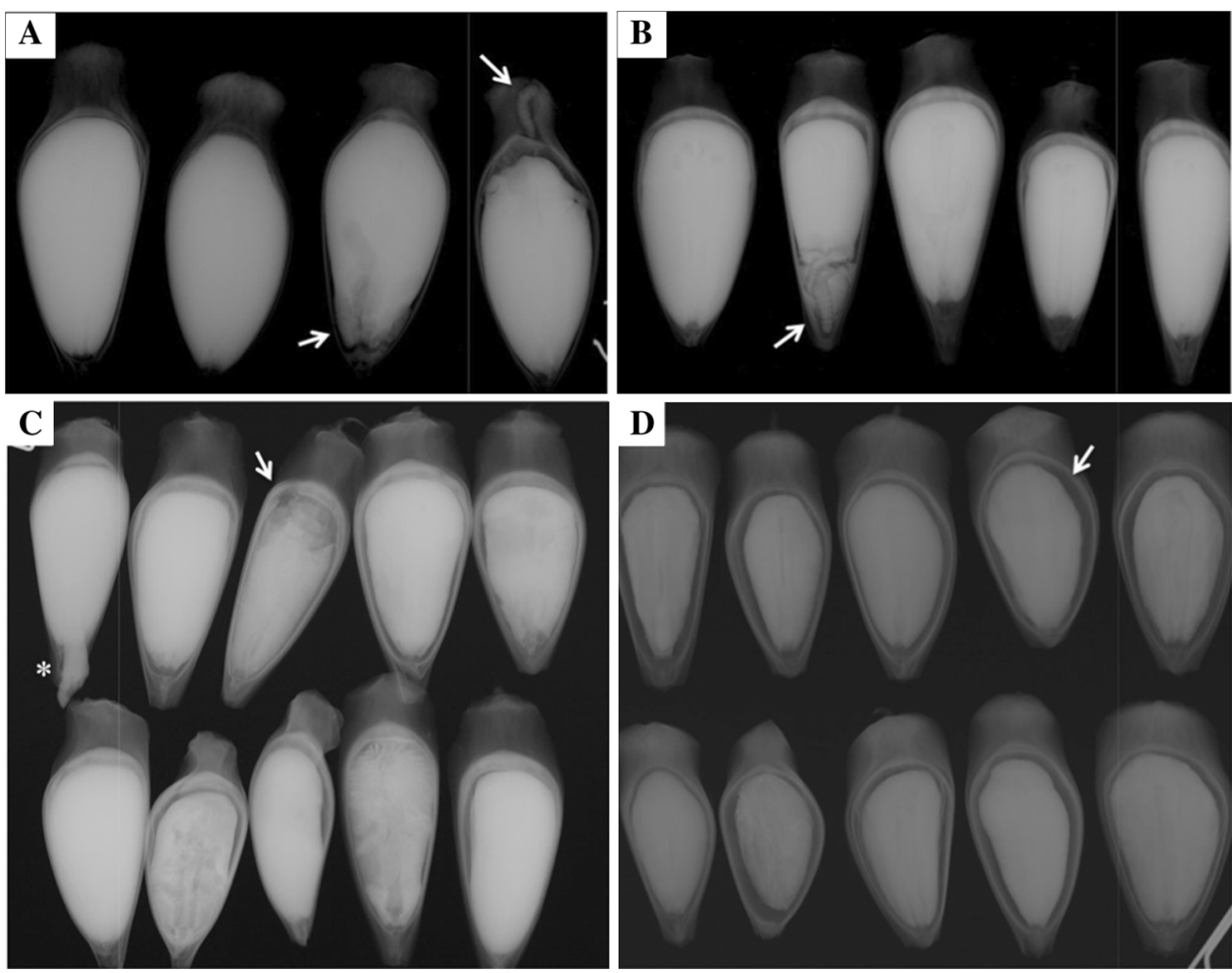


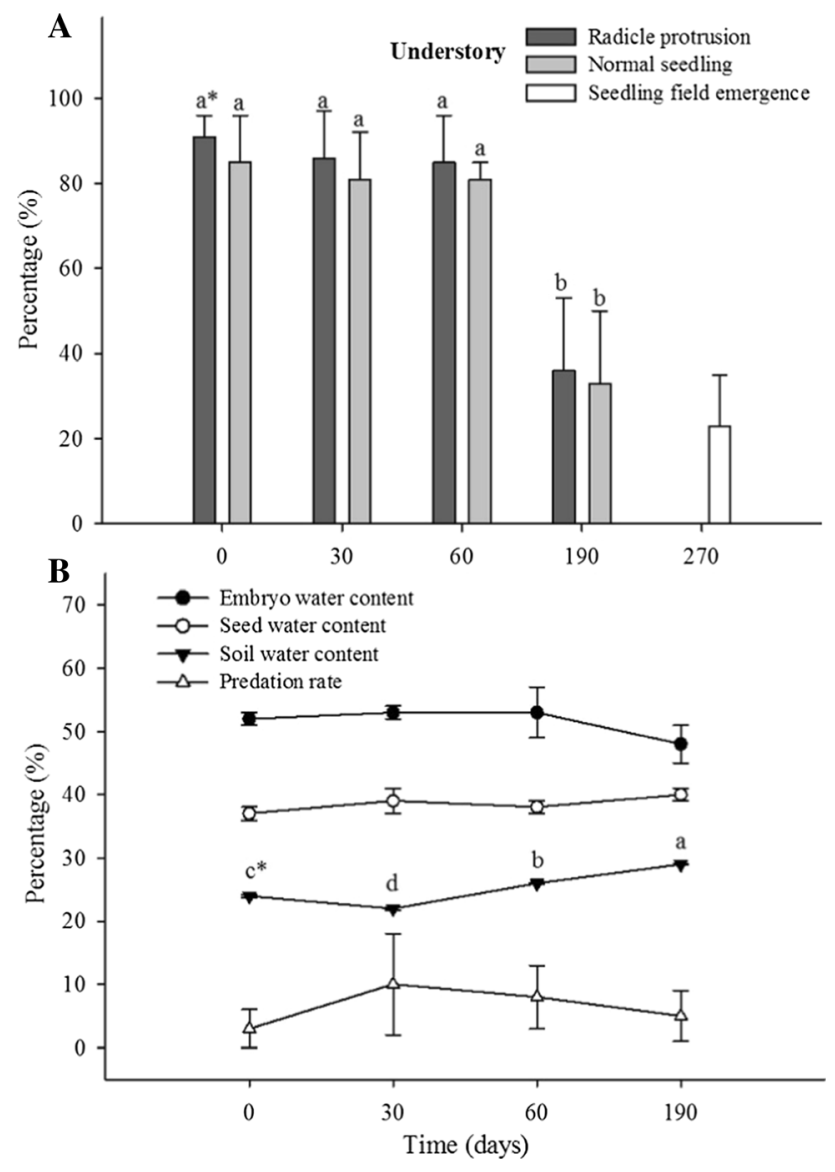

Fig. 4 Araucaria angustifolia seeds in induced seed bank in understory environment. a Radicle protrusion, normal seedling and emergence of seedlings in the field. b Embryo, seed and soil water contents, and seed predation rate during the experimental period from May 2014 (time zero) to January 2015 (270 days). *Means followed by the same letter indicate no difference according to Tukey test at $5 \%$. Bars represent standard deviation

germination decreased abruptly to $36 \% \pm 17 \%$ for radicle protrusion and $33 \% \pm 17 \%$ for normal seedlings (Fig. $4 a$ ). Seed and embryo water contents were not significantly different throughout the period (Fig. 4b). There was no significant difference in percent seed predation throughout the study, generally remaining less than $10 \%$ in all evaluations. At 270 days, the last evaluation, seedling emergence was observed in the understory seed bank, reaching $23 \% \pm 12 \%$. The remaining seeds were dead and decaying. Seedling emergence in the field took place during the rainy season when the highest rainfalls were recorded on days 210 and 240, and associated with a constant increase in temperatures (Fig. 6). Soil water content followed the same pattern as rainfall amounts, significantly varying throughout the study period with highest value on day 190 (Fig. 4b).

The seed bank at the forest edge showed significant differences (for all variables over the study period $(p$ $\leq 0.05$ ). Viability progressively decreased to $40 \% \pm 11 \%$

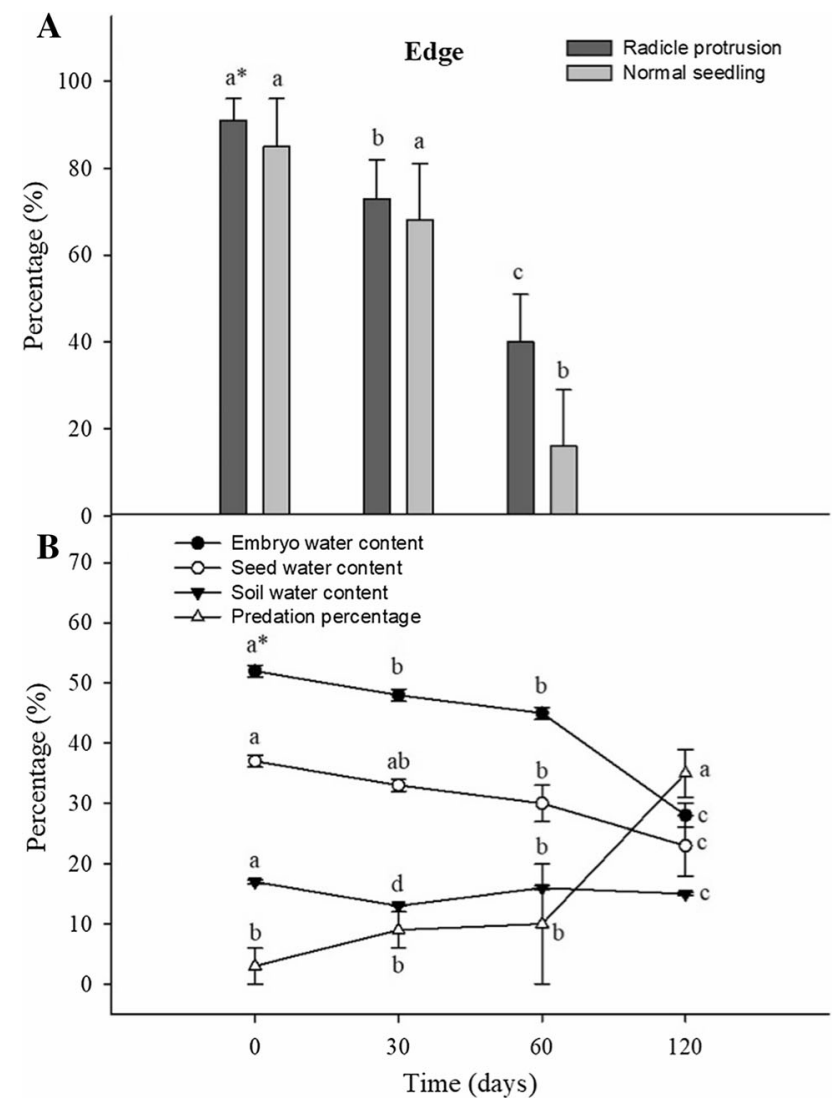

Fig. 5 Araucaria angustifolia seeds in induced seed bank at the forest edge. a Radicle protrusion and normal seedling. b Embryo, seed and soil water contents, and seed predation rate during the experimental period from May 2014 (time zero) to January 2015 (270 days). *Means followed by the same letter indicate no difference according to Tukey test at 5\%. Bars represent standard deviation

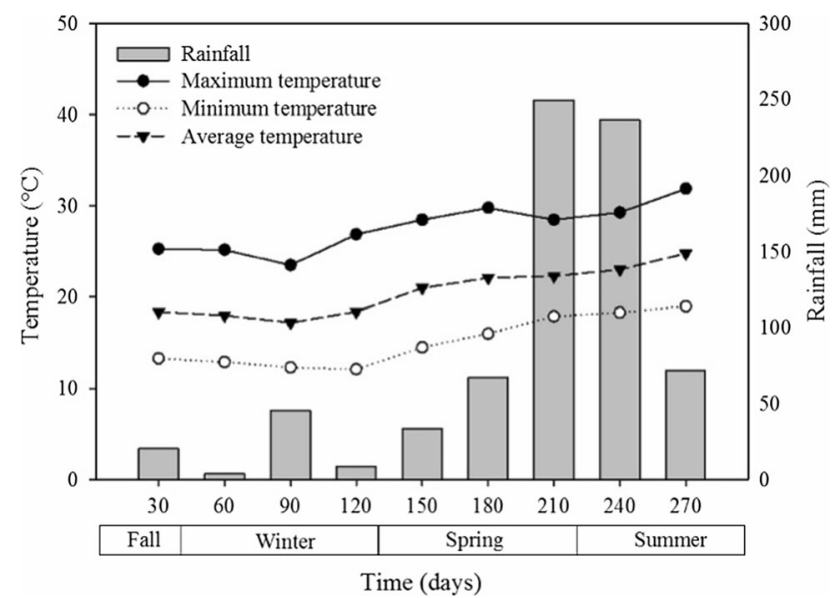

Fig. 6 Climatic data for the experiment site obtained from the Climatological Station (Department of Engineering, Federal University of Lavras), $10 \mathrm{~km}$ from the site

for radicle protrusion and $16 \% \pm 13 \%$ for normal seedlings by 60 days. After 120 days, there was a total loss of seed viability, and seedling emergence did not occur 
(Fig. 5a). Decrease in germination was followed by a decrease in seed and embryo water contents. At the final assessment, water content was $22.6 \% \pm 5.2 \%$ for seeds and $28.2 \% \pm 2.1 \%$ for embryos (Fig. 5 b). Seed predation showed no significant variation until day 60. At 120 days, however, a significant increase was observed $(35 \% \pm 4 \%)$. Soil water content $(17.4 \pm 0.31 \%$ /time zero) was higher at the beginning of the experiment. There was variation in the soil water values as influenced by rainfall, reaching their lowest at 30 days $(13.4 \% \pm 0.06 \%)$, coinciding with the lowest rainfall at the beginning of winter.

\section{Discussion}

The results in this study show that long-term storage using conventional techniques is not possible for seeds of $A$. angustifolia. On the other hand, for short-term storage up to 12 months, seed viability was high for both seeds lots when placed in sealed polyethylene bags and stored in a cold room. Despite the distinct features of the two provenances, there was no difference in storage behavior. At the Aiuruoca River Basin where the MG provenance originated, the predominant climate, according to Köppen's classification, is $C w a$, with an annual average temperature of $18{ }^{\circ} \mathrm{C}$, a minimum average of $13{ }^{\circ} \mathrm{C}$ and a maximum average of $21^{\circ} \mathrm{C}$, and $1500 \mathrm{~mm}$ annual rainfall (Viola et al. 2009). At Campos de Cima da Serra where RS provenance originated, the climate is $C f b$, with an annual average temperature of $14.5^{\circ} \mathrm{C}$, a minimum average of $3{ }^{\circ} \mathrm{C}$ and a maximum average of $22{ }^{\circ} \mathrm{C}$, and $2500 \mathrm{~mm}$ annual rainfall. This is one of the most humid regions in Rio Grande do Sul, and there are frequent frosts and occasional snow in winter (Moreno 1961; Nimer 1990).

Climate features may influence seed production during the maturation and adaptation of a species to a given environment. For example, Quercus ilex L. recalcitrant seeds from different geographic regions showed similar physiological features except for electrical conductivity, which was higher for a seed lot characterized by restrictions in water availability during maturation (Pasquini et al. 2011). When electrical conductivity values were compared in the present study, the MG provenance had higher values than the RS provenance for both fresh and stored seeds; however, viability was high for both for a period of one year according to germination tests.

Loss of viability during storage has been associated with a loss of cell membrane integrity resulting in increased leaching according to a study on Moringa oleifera Lam. seeds in which an increase in electrical conductivity was observed throughout storage (Fotouo-M et al. 2015). In addition, low electrical conductivity has been associated with high germination rates of A. angustifolia seeds (Shibata et al. 2013).

One interesting aspect of the present study is the variation in water contents for both seed and embryos during storage. For MG provenance, seed viability and water contents decreased simultaneously with the lowest value of $28.5 \%$ associated with lowest germination. However, water content of the seed for the RS provenance increased by 7.4 percentage points during storage and was accompanied by a reduction in viability, i.e., germination was reduced at $41 \%$ water content if initial and final values are compared.

Recalcitrant seeds are dispersed with high water content, and dehydration down to approximately $20 \%$ results in death by desiccation (Daws et al. 2006). A. angustifolia seeds are classified as recalcitrant with a critical water content between 37 and $38 \%$, and lethal water content of approximately 25\% (Tompsett 1984; Eira et al. 1994). The embryo loses viability when dehydrated to approximately 43\% (Espindola et al. 1994). In the present study, a total loss of embryo viability was found after 26 months of storage for $\mathrm{MG}$ provenance at $48 \%$ water content. A reduction of 20 percentage points in seed water content after 21 days of storage in silica gel resulted in sub-cellular deterioration. Further, when water content was reduced by 26 percentage points, plasma membranes withdrew from cell walls, followed by compaction of cytoplasm and loss of viability (Farrant et al. 1989). However, it has been suggested that recalcitrant seeds may be dehydrated to a certain level without significant damage to their physiological potential (Eggers et al. 2007; Umarani et al. 2015).

The increase in water content of seeds during storage may be associated with higher respiration, resulting in an increase of water as observed in recalcitrant seeds of Quercus alba Houba stored in various environments (Iakovoglou et al. 2010). They also report that low $\mathrm{O}_{2}$ induces fermentation and consequently, loss of seed viability, in addition to the influence of water vapor condensation during storage which may also contribute to increased seed water content. Oxygen may influence seed deterioration by oxidation and low respiration rates in dry seeds compared to developing or germinating seeds (Bewley et al. 2013). Walters et al. (2001) observed that for both desiccation-sensitive and desiccation-tolerate seeds, viability remained high during drying and storage only when small amounts of oxygen were consumed.

In this study, $\mathrm{CO}_{2}$ release rates were almost always higher than rates of $\mathrm{O}_{2}$ uptake; high levels for both were observed in fresh RS provenance seeds. High respiration rates may also be associated with the presence of microflora. It has been suggested that one of the main causes of deterioration during storage of moist seeds of grey mangrove, Avicennia marina (Forssk.) Vierh., was infestation by microorganisms, especially fungi (Motete et al. 1997). 
In $A$. angustifolia seeds, high contamination by fungi was observed during both storage and germination test. This may be one of the factors related to higher respiratory activity at the end of the storage period of RS provenance and the concomitant loss of seed viability. Storage fungi may cause several damaging effects in seeds, such as viability loss, discoloration, production of mycotoxines and heat (Bewley et al. 2013).

The soil seed bank of $A$. angustifolia displayed different behaviors in understory and forest-edge environments. Seed water content after collection was relatively low $(37.5 \%)$ when compared to the seeds collected the previous year $(40.1 \%)$, which were used for the storage essays. However, seed water content after dispersal was at critical levels, which is, according to Tompsett (1984) and Eira et al. (1994), between 37 and 38\%. In another study with $A$. angustifolia, dehydration to $34 \%$ water content did not decrease seed viability (Gasparin et al. 2017). There appears to be year-to-year variations in critical water levels that may be influenced by climatic conditions during maturation. A. angustifolia seeds form a transient seed bank in an understory environment. Seeds remain viable for less than 1 year in the soil, are non-dormant, disperse during a short period in the year and are usually associated with the formation of a seedling bank (Thompson and Grime 1979; Gardwood 1989).

In the understory environment, seeds maintained high viability for 60 days, whereas at the forest edge, high viability was maintained for only 30 days. Loss of viability at the forest edge is associated with a significant reduction in soil water content coinciding with a period of lower rainfall. A considerable reduction in water content has been observed in both seed and embryos, reaching values below the lethal level after 120 days (Tompsett 1984; Eira et al. 1994; Espindola et al. 1994). Another study assessing drying rates in $A$. angustifolia seeds showed that total viability loss occurred when seeds and embryos reached water content values of between 23 and 33\%, respectively (Gasparin et al. 2017). Reduction in soil water contents is thus associated with a decrease in seed germination, as reported for Quercus rubra L. (García et al. 2002).

Seeds of A. angustifolia remained viable in the understory seed bank and $23 \%$ produced emergent seedlings. The presence of vegetation is important for this species because it allows for the creation of a microclimate favorable for the establishment of a transient seed bank. Germination and seedling establishment in this environment coincided with the period of highest rainfall (end of spring and beginning of summer), as well as with an increase in monthly average temperatures. High water availability is associated with high water content in the soil. However, the presence of vegetation seems to have had a fundamental role in the maintenance of seed water contents, which remained above the critical level during the experimental period to promote seedling emergence. There is considerable evidence showing the influence of soil water and favorable climatic conditions on seed viability in the soil (Fenner and Thompson 2005). Some tropical species produce seeds in the dry season which results in a delay in germination; however, with the onset of the rainy season, seeds germinate and seedlings emerge (Vazquez-Yanes and Orozco-Segovia 1993).

A study in the same area as this research with desiccation-sensitive $C$. aschersoniana Mez. seeds, demonstrated that the formation of a transient seed bank is related to the preservation of the natural habitat of the species (Tonetti et al. 2015). Similar behavior was observed in this study, implying that anthropization, (the adaption of an environment to meet human needs), negatively affects the establishment of species that produce desiccation-sensitive seeds. The effect of forest fragmentation was also unfavorable for the germination of Heliconia acuminata A.Rich., an Amazonian species. When compared to the environment of the continuous forest, three to seven times fewer seeds germinated in the altered edge environment (Bruna 1999).

Several studies describe the absence of $A$. angustifolia in the soil seed bank, which may be related to their recalcitrant nature and to the pressure by both fauna and humans (Avila et al. 2011; Souza et al. 2011). In some cases, despite A. angustifolia dominating the canopy, it does not regenerate naturally (Caldato et al. 1996). Considering the auto-ecological features of the species, the main regeneration strategy for A. angustifolia is by seed rain associated with a seedling bank. Since the species is light-demanding, the presence of light is vital for regeneration (Avila et al. 2011, 2013). Desiccation sensitivity and the brief longevity of recalcitrant seeds directly affect regeneration, resulting in the absence of a long-term, persistent soil seed bank (Pammenter and Berjak 2000).

The emergence of seedlings from a soil seed bank depends on a range of environmental factors of which water and temperature are the most important (Bewley et al. 2013). Light is not essential for germination since almost all species produce seeds that are neutral photoblastic, although photosynthesis is required for growth after germination (Ferraz and Calvi 2011). Seedlings of $A$. angustifolia have normal growth under high to moderate solar radiation in the initial stages; however low radiance levels contribute to poor seedling development (da Duarte and Dillenburg 2000). Young plants of Brazilian pine grown under shade for lengthy periods showed morphological changes such as stretching and slender stems and shoots (Dillenburg et al. 2009). Excessive shading is one of the factors that may limit the regeneration of this species in a forest understory. 
This study showed that $A$. angustifolia has the potential to form a transient seed bank. Nevertheless, it is necessary to isolate the predation factor for success, and in this investigation, metal cages were used to protect the seeds. In a previous study without protection, all seeds were preyed upon by rodents after 30 days (data not shown). Further, predation percentage of $A$. angustifolia seeds may be higher at the forest edge than in the understory, especially regarding larvae infestation. Wild fauna, besides preying upon seeds, may contribute to their dispersal and to the establishment of species in a given environment. In the case of A. angustifolia, the azure jay, (Cyanocorax caeruleus Vieillot), plays a fundamental role in seed dispersal, burying seeds in a given place with the intention of hiding them from predators, and these seeds frequently germinate (Mattos 2011).

This study shows that only short-term storage of $A$. angustifolia seeds is possible under refrigeration for approximately 12 months, and provenance did not affect storability, despite distinct climatic features in the regions under consideration. Further, the maintenance of a forest cover is fundamental for the regeneration and conservation of $A$. angustifolia to form a transient seed bank, as forest edge conditions are unfavorable for regeneration.

Acknowledgements The authors thank the Coordination for the Improvement of Higher Level Personnel (CAPES, Brazil) for granting the main author's scholarship, the Brazilian Institute of the Environment and Renewable Natural Resources (IBAMA) for authorizing seed collection in the different locations (License No 34243-3), the FLONA (São Francisco de Paula/RS) for help in seed collection of RS provenance, and to anonymous reviewers for valuable contributions.

Open Access This article is distributed under the terms of the Creative Commons Attribution 4.0 International License (http://crea tivecommons.org/licenses/by/4.0/), which permits unrestricted use, distribution, and reproduction in any medium, provided you give appropriate credit to the original author(s) and the source, provide a link to the Creative Commons license, and indicate if changes were made.

\section{References}

Abreu DCA, Medeiros AC de S, Aguiar IB, Banzatto DA (2012) Teste topográfico de tetrazólio em sementes de pinheirobrasileiro (Araucaria angustifolia (Bertol.) Kuntze). In: $4^{\circ}$ Congresso Florestal Paranaense. Curitiba

Avila AL, Araujo MM, Longhi SJ, Gasparin E (2011) Agrupamentos florísticos na regeneração natural em remanescente de Floresta Ombrófila Mista, RS, Brasil. Sci For 39:331-342

Avila AL, Araujo MM, Gasparin E, Longhi SJ (2013) Mecanismos de regeneração natural em remanescente de Floresta Ombrófila Mista, RS, Brasil. Cerne 19:621-628

Barbedo CJ, Bilia DAC (1998) Evolution of research on recalcitrant seeds. Sci Agric 55:121-125

Berjak P, Pammenter NW (2000) What ultrastructure has told us about recalcitrant seeds. Rev Bras Fisiol Veg 12:22-25
Bewley JD, Bradford KJ, Hilhorst HW, Nonogaki H (2013) Seeds: physiology of development, germination and dormancy, 3rd edn. Springer, New York

Bruna EM (1999) Seed germination in rainforest fragments. Nature 402:139. https://doi.org/10.1038/45963

Caldato SL, Floss PA, Da Croce DM, Longhi SJ (1996) Estudo da regeneração natural, banco de sementes e chuva de sementes na Reserva Genética Florestal de Caçador, Sc. Ciência Florest 6:27-38

Carvalho PER (2002) Pinheiro-do-paraná. Circ Técnica Embrapa 60:1-17

da Duarte LS, Dillenburg LR (2000) Ecophysiological responses of Araucaria angustifolia (Araucariaceae) seedlings to different irradiance levels. Aust J Bot 48:531-537

Daws MI, Garwood NC, Pritchard HW (2006) Prediction of desiccation sensitivity in seeds of woody species: a probabilistic model based on two seed traits and 104 species. Ann Bot 97:667-674. https://doi.org/10.1093/aob/mcl022

Dillenburg LR, Franco AMS, Coutinho AL, Korndorfer CL, Clebsch CC, Duarte LS, Ferla L, Rosa LMG, Silva LGR, Garbin ML, Mósena M, Zandavalli RB, Yamasaki S (2009) Aspectos ecofisiológicos da regeneração e crescimento de Araucaria angustifolia. In: Fonseca CR, Souza AF, Leal-Zanchet AM, Dutra T, Backes A, Ganado G (eds) Floresta de Araucária: Ecologia, Conservação e Desenvolvimento Sustentável. Holos, Ribeirão Preto, pp 57-65

Eggers S, Erdey D, Pammenter NW, Berjak P (2007) Storage and germination response of recalcitrant seeds subjected to mild dehydration. In: Adkins SW, Ashmore SE, Navie S (eds) Seeds: biology, development and ecology. CAB International, London, pp 85-92

Eira MTS, Salomão AN, Cunha R, Carrara DK, Mello CMC (1994) Efeito do teor de água sobre a germinação de sementes de Araucaria angustifolia (BERT.) O. KTZE-Araucariaceae. Rev Bras Sementes 16:71-75

Espindola LS, Noin M, Corbineau F, Côme D (1994) Cellular and metabolic damage induced by desiccation in recalcitrant Araucaria angustifolia embryos. Seed Sci Res 4:193-201

Farrant JM, Pammenter NW, Berjak P (1989) Germination-associated events and the desiccation sensitivity of recalcitrant seeds-a study on three unrelated species. Planta 178:189-198

Fenner M, Thompson K (2005) The ecology of seeds. Cambridge University Press, New York

Ferraz IDK, Calvi GP (2011) Teste de Germinação. In: Lima Junior MJ (ed) Manual de Procedimentos de Análise de Sementes Florestais. Abrates, Londrina, pp 5-36

Ferreira DF (2008) Sisvar: um programa para análises e ensino de estatística. Rev Sympos 6:36-41

Fotouo-M H, du Toit ES, Robbertse PJ (2015) Germination and ultrastructural studies of seeds produced by a fast-growing, drought-resistant tree: implications for its domestication and seed storage. AoB Plants 7:plv016. https://doi.org/10.1093/ aobpla/plv016

García D, Bañuelos M-J, Houle G (2002) Differential effects of acorn burial and litter cover on Quercus rubra recruitment at the limit of its range in eastern North America. Can J Bot 80:1115-1120. https://doi.org/10.1139/b02-102

Gardwood NC (1989) Tropical soil seed banks: a review. In: Leck M, Parker V, Simpson R (eds) Ecology of soil seed banks. Academic Press, San Diego, pp 149-209

Gasparin E, Faria JMR, José AC, Hilhorst HWM (2017) Physiological and ultrastructural responses during drying of recalcitrant seeds of Araucaria angustifolia. Seed Sci Technol 1:1-18

Guerra MP, Silveira V, Santos ALW, Astarita LV, Nodari RO (2000) Somatic embryogenesis in Araucaria angustifolia (Bert) O. Kuntze. In: Jain SM, Gupta PK, Newton RJ (eds) Somatic 
embryogenesis in woody plants. Kluwer Academic Publishers, Dordrecht, pp 457-578

Iakovoglou V, Misra MK, Hall RB, Knapp AD (2010) Alterations of seed variables under storage in nitrous oxide $\left(\mathrm{N}_{2} \mathrm{O}\right)$ atmospheres for two recalcitrant Quercus species. Scand J For Res 25:24-30. https://doi.org/10.1080/02827581.2010.485778

ISTA (1996) International rules for seed testing. Seed Sci Technol 24:48-52

IUCN (2016) The IUCN red list of threatened species. Version 2015-4. www.iucnredlist.org. Accessed 18 Mar 2016

Lauterjung MB, Bernardi AP, Montagna T, Candido-Ribeiro R, Costa NCF, Mantovani A, Reis MS (2018) Phylogeography of Brazilian pine (Araucaria angustifolia): integrative evidence for pre-Columbian anthropogenic dispersal. Tree Genet Genomes 14:1-12. https://doi.org/10.1007/s11295-018-1250-4

Leite PF (2002) Contribuição ao conhecimento fitoecológico do Sul do Brasil. Ciência Ambient 1:51-73

Long RL, Gorecki MJ, Renton M, Scott JK, Colville L, Goggin DE, Commander LE, Westcott DA, Cherry H, Finch-Savage WE (2015) The ecophysiology of seed persistence: a mechanistic view of the journey to germination or demise. Biol Rev 90:31-59. https://doi.org/10.1111/brv.12095

Mattos JR (2011) O pinheiro brasileiro. Editora da UFSC, Florianópolis

Moreira-Souza M, Cardoso EJBN (2003) Practical method for germination of Araucaria angustifolia (Bert.) O. Ktze. seeds. Sci Agric 60:389-391

Moreno JA (1961) Clima do Rio Grande do Sul. Secretaria da Agricultura, Porto Alegre

Motete N, Pammenter NW, Berjak P, Frédéric JC (1997) Response of the recalcitrant seeds of Avicennia marina to hydrated storage: events occurring at the root primordia. Seed Sci Res 7:169-178. https://doi.org/10.1017/S0960258500003500

Nimer E (1990) Geografia do Brasil: Região Sul. In: IBGE-Instituto Brasileiro de Geografia e Estatística. IBGE, Rio de Janeiro, pp 51-187

Oliveira-Filho A, Fontes MAL (2000) Patterns of floristic differentiation among Atlantic Forests in Southeastern Brazil and the influence of climate. Biotropica 32:793-810. https://doi.org/10. 1111/j.1744-7429.2000.tb00619.x

Pammenter NW, Berjak P (2000) Evolutionary and ecological aspects of recalcitrant seed biology N.W. Seed Sci Res 10:301-306

Pasquini S, Braidot E, Petrussa E, Vianello A (2011) Effect of different storage conditions in recalcitrant seeds of holm oak (Quercus ilex L.) during germination. Seed Scince Technol 39:165-177

Probert RJ, Daws MI, Hay FR (2009) Ecological correlates of ex situ seed longevity: a comparative study on 195 species. Ann Bot 104:57-69. https://doi.org/10.1093/aob/mcp082

Saatkamp A, Affre L, Dutoit T, Poschlod P (2009) The seed bank longevity index revisited: limited reliability evident from a burial experiment and database analyses. Ann Bot 104:715-724. https://doi.org/10.1093/aob/mcp148

Saatkamp A, Poschlod P, Venable DL (2014) The functional role of soil seed banks in natural communities. In: Gallagher RS (ed) Seeds: the ecology of regeneration in plant communities, 3rd edn. CAB International, Wallingford, pp 263-295
Shibata M, Coelho CMM, Steiner N (2013) Physiological quality of Araucaria angustifolia seeds at different stages of development. Seed Sci Technol 41:214-224

Souza AF, Forgiarini C, Longhi SJ, Brena DA (2008) Regeneration patterns of a long-lived dominant conifer and the effects of logging in southern South America. Acta Oecol 34:221-232. https://doi.org/10.1016/j.actao.2008.05.013

Souza ML, Nogueira AC, Macedo RLG, Sanquetta CR, Venturin N (2011) Estudos de um banco de sementes no solo de um fragmento florestal com Araucaria angustifolia no estado do Paraná. Floresta 41:335-346

Thompson K (2000) The functional ecology of soil seeds banks. In: Fenner M (ed) Seeds: the ecology of regeneration in plant communities, 2nd edn. CABI Publishing, Wallingford, pp 215-235

Thompson K, Grime JP (1979) Seasonal variation in the seed banks of herbaceous species in ten contrasting habitats. $J$ Ecol 67:893-921

Thys RCS, Noreña CPZ, Marczak LDF, Aires AG, Cladera-Oliveira F (2010) Adsorption isotherms of pinhão (Araucaria angustifolia seeds) starch and thermodynamic analysis. J Food Eng 100:468-473. https://doi.org/10.1016/j.jfoodeng.2010.04.033

Tompsett PB (1982) The effect of desiccation on the longevity of seeds of Araucaria hunsteinii and A. cunninghamii. Ann Bot 50:693-704

Tompsett PB (1984) Desiccation studies in relation to the storage of Araucaria seed. Ann Appl Biol 105:581-586

Tonetti OAO, Faria JMR, José AC, Oliveira TGS, Martins JC (2015) Seed survival of the tropical tree Cryptocarya aschersoniana (Lauraceae): consequences of habitat disturbance. Austral Ecol. https://doi.org/10.1111/aec.12305

Tweddle JC, Dickie JB, Baskin CC, Baskin JM (2003) Ecological aspects of seed desiccation sensitivity. J Ecol 91:294-304. https://doi.org/10.1046/j.1365-2745.2003.00760.x

Umarani R, Aadhavan EK, Faisal MM (2015) Understanding poor storage potential of recalcitrant seeds. Curr Sci 108:2023-2034

Vazquez-Yanes C, Orozco-Segovia A (1993) Patterns of seed longevity and germination in the Tropical Rainforest. Annu Rev Ecol Syst 24:69-87. https://doi.org/10.1146/annurev.es.24. 110193.000441

Viola MR, Mello CR, Acerbi FW Jr, Silva AM (2009) Modelagem hidrológica na bacia hidrográfica do Rio Aiuruoca, MG. Rev Bras Eng Agrícola e Ambient 13:581-590

Walters C (2015) Orthodoxy, recalcitrance and in-between: describing variation in seed storage characteristics using threshold responses to water loss. Planta 242:397-406. https://doi.org/10. 1007/s00425-015-2312-6

Walters C, Pammenter NW, Berjak P, Crane J (2001) Desiccation damage, accelerated ageing and respiration in desiccation tolerant and sensitive seeds. Seed Sci Res 11:135-148. https:// doi.org/10.1079/SSR200168

Wendling I, Delgado ME (2008) Produção de mudas de araucária em tubetes. Comun Técnico Embrapa 201:1-18

Publisher's Note Springer Nature remains neutral with regard to jurisdictional claims in published maps and institutional affiliations. 